\title{
FAKTOR RISIKO OVERWEIGHT DAN OBESE PADA ORANG DEWASA DI INDONESIA (Analisis Data Riset Kesehatan Dasar 2013)
}

\author{
Risk Factors of Overweight and Obese in Indonesian Adults \\ (Analysis Data of Basic Health Research 2013)
}

Sudikno' ${ }^{1}$, Hidayat Syarief², Cesilia Meti Dwiriani ${ }^{2}$, Hadi Riyadi²

${ }_{1}^{1}$ Pusat Teknologi Intervensi Kesehatan Masyarakat, Balitbangkes, Kemenkes RI, Jl. Percetakan Negara No.29 Jakarta

${ }^{2}$ Fakultas Ekologi Manusia (FEMA), Institut Pertanian Bogor (IPB), Bogor

E-mail: onkidus@gmail.com

\begin{abstract}
The problem of overweight and obese in Indonesia had a trend of rising along with the increasing age of the population. This study aimed to identify risk factors associated with overweight and obese adults aged 25-65 years in Indonesia using Riskesdas 2013 data. The study design was cross-sectional. Samples were adults aged 25-65 years in Indonesia with the total of 458591 people. Results showed that the prevalence of overweight and obese at the age of 25-65 years were found to be 26.1 percent and 7.20 per cent, respectively. The mean of Body Mass Index (BMI) was $24.02 \pm 3.70 \mathrm{~kg} / \mathrm{m}^{2}$. The results of logistic regression analysis showed that the risk factors associated with overweight and obese were age, sex, region, marital status, employment, economic status, and smoking habits. The result also showed that the habits of eating bread and biscuit were also associated with the incidence of obese. Hence, prevention efforts such as sufficient regular physical activities are needed. In addition, it is also necessary to promote food substitute for carbohydrates source to meet balanced nutrition both in number and type, as well as the quality.
\end{abstract}

Keywords: risk factors, overweight, obese, Indonesian adults

\begin{abstract}
ABSTRAK
Masalah overweight dan obese di Indonesia mengalami kecenderungan naik seiring dengan meningkatnya umur penduduk. Penelitian ini bertujuan untuk mengetahui faktor risiko yang berhubungan dengan overweight dan obese pada orang dewasa umur 25-65 tahun di Indonesia. Penelitian ini menggunakan data Riskesdas 2013. Desain penelitian adalah cross-sectional. Sampel penelitian adalah orang dewasa berumur 25-65 tahun di Indonesia. Jumlah sampel yang dianalisis 458591 orang. Hasil analisis menunjukkan prevalensi overweight pada usia 25-65 tahun ditemukan sebesar 26,1 persen, sedangkan prevalensi obese pada usia 25-65 tahun sebesar 7,2 persen. Rata-rata Indeks Massa Tubuh (IMT) adalah $24,02 \pm 3,70 \mathrm{~kg} / \mathrm{m}^{2}$. Dari hasil analisis regresi logistik menunjukkan bahwa faktor risiko yang berhubungan dengan overweight dan obese adalah umur, jenis kelamin, wilayah, status kawin, pekerjaan, status ekonomi, kebiasaan merokok. Selanjutnya diperoleh hasil juga bahwa kebiasaan makan roti dan kebiasaan makan biskuit juga berhubungan dengan kejadian obese. Perlu adanya upaya pencegahan seperti dengan aktivitas fisik yang cukup setiap hari secara berkesinambungan. Di samping itu diperlukan juga upaya promosi pemilihan makanan pengganti sumber karbohidrat dalam pemenuhan gizi seimbang baik dalam jumlah maupun jenis, serta kualitasnya.
\end{abstract}

Kata kunci: faktor risiko, overweight, obese, orang Indonesia dewasa

\section{PENDAHULUAN}

Di seluruh dunia, proporsi orang dewasa dengan indeks massa tubuh (IMT) $25 \mathrm{~kg} / \mathrm{m}^{2}$ atau lebih meningkat antara tahun 1980-2013 dari 28,8 persen menjadi 36,9 persen pada pria, dan dari 29,8 persen menjadi 38,0 persen pada wanita. Di negara berkembang (termasuk 
negara dengan ekonomi berpenghasilan rendah dan menengah) memiliki tingkat prevalensi yang lebih rendah dibandingkan negara maju, namun mengalami peningkatan prevalensi tiga kali lebih tinggi daripada negara-negara maju sejak tahun 1990.1

Caballero (2007) mengungkapkan bahwa prevalensi overweight dan obese terus meningkat baik di negara maju maupun negara berkembang. ${ }^{2}$ Hasil review yang dilakukan Low et al. (2009) menunjukkan prevalensi overweight dan obese di negara maju dan negara berkembang mengalami peningkatan. ${ }^{3}$ Pada tahun 2008, diperkirakan 1,46 miliar orang dewasa di seluruh dunia mengalami kegemukan (body-mass index [BMl] $>25 \mathrm{~kg} / \mathrm{m}^{2}$ ) dan 502 juta orang dewasa mengalami obese (BMl> 30 $\left.\mathrm{kg} / \mathrm{m}^{2}\right)^{4}$, dan diperkirakan pada tahun 2030 sekitar 2.16 miliar orang dewasa di dunia mengalami overweight, dan 1,12 miliar akan menjadi obese. ${ }^{5}$

Data prevalensi overweight dan obese secara nasional di Indonesia juga menunjukkan adanya peningkatan dari tahun ke tahun. Penelitian Kodyat et al. (1996) di 12 Kotamadya mendapatkan prevalensi overweight (IMT $=25$ $27 \mathrm{~kg} / \mathrm{m}^{2}$ ) sebesar 10,3 persen dan prevalensi obese (IMT>=27 kg/m²) sebesar 12,2 persen ${ }^{6}$. Hasil analisis Riset Kesehatan Dasar 2007 menunjukkan prevalensi IMT>27 $\mathrm{kg} / \mathrm{m}^{2}$ penduduk dewasa di Indonesia (umur 18 tahun ke atas) sebesar 12,47.7 Prevalensi IMT>25 $\mathrm{kg} / \mathrm{m}^{2}$ penduduk laki-laki dewasa ( $>18$ tahun) pada tahun 2013 sebesar 19,7 persen, lebih tinggi daripada tahun 2007 (13.9\%) dan tahun 2010 (7,8\%). Sedangkan prevalensi IMT>25 $\mathrm{kg} / \mathrm{m}^{2}$ perempuan dewasa ( $>18$ tahun) pada tahun 2013 sebesar 32,9 persen, naik 18,1 persen dari tahun $2007(13,9 \%)$ dan 17,5 persen dari tahun $2010(15,5 \%){ }^{8}$

Overweight dan obese merupakan faktor risiko dari berbagai penyakit degeneratif, seperti: diabetes mellitus tipe 2, hipertensi, penyakit jantung, dan kanker. ${ }^{9}$ Asosiasi Jantung Amerika (AHA) mengidentifikasi obese sebagai faktor risiko utama dari cardiovascular disease (CVD) (WHO 2000). ${ }^{10}$ Studi kohor yang diambil dari empat klinik di Birmingham, Chicago, Minneapolis, dan Oakland pada dewasa muda (18-30 tahun) menunjukkan bahwa pada mereka yang meningkat berat badannya lebih dari $2,5 \mathrm{~kg}$ dalam 15 tahun mengalami perubahan yang tidak menguntungkan dalam faktor risiko CVD dan tingginya angka kejadian sindrom metabolik dan komponennya, seperti: lemak dan tekanan darah. ${ }^{11}$

Penelitian Lestari dan Siswanto (2007) ${ }^{12}$ menyimpulkan bahwa obese secara bermakna berpengaruh terhadap kejadian diabetes mellitus. Pada subyek dengan obese dan termasuk kelompok dengan pendapatan pada kuintil III mempunyai risiko kejadian diabetes mellitus sebesar 2,6 kali (CI 95\%: 1,205-5,494) dibanding subyek dengan berat badan normal dan kelompok pendapatan pada kuintil I. Sedangkan pada subyek yang mengalami obese dan termasuk kelompok dengan pendapatan pada kuintil $\mathrm{V}$ (kelompok terkaya) memiliki risiko kejadian diabetes mellitus sebesar 2,1 kali (Cl 95\%: 1,078-4,017) dibanding subyek dengan berat badan normal dan kelompok pendapatan pada kuintil I. Hasil penelitian Sihombing $\mathrm{M}$ dan Tjandrarini $\mathrm{DH}$ (2015) terhadap orang dewasa umur 25-65 tahun di Kota Bogor menunjukkan bahwa obesitas berhubungan dengan sindrom metabolik. ${ }^{13}$

Mukherjee et al. (2013) mengungkapkan bahwa faktor-faktor terkait dengan kejadian obese meliputi: faktor lingkungan dan sosial, gangguan sistem syaraf dan endokrin, faktor gaya hidup, konsumsi makanan tinggi lemak, konsumsi makanan berlebihan, umur, faktor psikologi/stress, perilaku merokok, dan konsumsi alkohol. ${ }^{14}$

Obesitas terkait dengan peningkatan status sosial ekonomi masyarakat erat kaitannya dengan perubahan gaya hidup, termasuk dalam perubahan pola makan. Konsumsi padi-padian menurun, sedangkan persentase energi dari konsumsi lemak meningkat. Di samping itu juga terjadi perubahan dalam kebiasaan makan keluarga. Adanya kecenderungan keluarga untuk makan di luar rumah, dan adanya peningkatan konsumsi makanan cepat saji, penggunaan lebih banyak minyak nabati dan minuman manis. Selanjutnya perubahan gaya hidup yang signifikan lainnya adalah aktifitas fisik yang cenderung menurun di masyarakat dan meningkatnya waktu luang. ${ }^{15,16}$

Riset Kesehatan Dasar (Riskesdas) tahun 2013 menyediakan data dan prevalensi overweight dan obese dan belum dilakukan analisis lebih lanjut. Analisis ini akan dilakukan terhadap kelompok umur sampel 25-65 tahun. 
Beberapa hasil penelitian menunjukkan bahwa risiko penyakit tidak menular termasuk kejadian obesitas terjadi pada umur 25 tahun ke atas. Penelitian ini bertujuan untuk mengetahui faktor risiko yang berhubungan dengan overweight dan obese pada orang dewasa umur 25-65 tahun di Indonesia berdasarkan Riset Kesehatan Dasar 2013.

\section{METODE PENELITIAN}

Riskesdas 2013 adalah sebuah survei dengan desain cross-sectional. Riskesdas 2013 dimaksudkan untuk menggambarkan masalah kesehatan penduduk di seluruh pelosok Indonesia, yang terwakili oleh penduduk di tingkat nasional, provinsi, dan kabupaten/kota.

Kerangka sampel Riskesdas 2013 terdiri dari dua jenis, yaitu kerangka sampel untuk penarikan sampel tahap pertama dan kerangka sampel untuk penarikan sampel tahap kedua. Kerangka sampel pemilihan tahap pertama adalah daftar primary sampling unit (PSU) dalam master sampel. Jumlah PSU dalam master sampel adalah 30.000 yang dipilih secara probability proportional to size (PPS) dengan jumlah rumah tangga hasil sensus penduduk (SP) 2010. PSU adalah gabungan dari beberapa blok sensus (BS) yang merupakan wilayah kerja tim pencacahan SP2010. PSU juga dilengkapi informasi jumlah dan daftar nama kepala rumah tangga, alamat, tingkat pendidikan kepala rumah tangga berdasarkan klasifikasi wilayah urban/rural.

Sedangkan kerangka sampel pemilihan tahap kedua adalah seluruh bangunan sensus yang di dalamnya terdapat rumah tangga biasa tidak termasuk institutional household (panti asuhan, barak polisi/militer, penjara, dsb) hasil pencacahan lengkap SP2010 (SP2010-C1). Bangunan sensus terpilih dan rumah tangga di dalam bangunan sensus terpilih terlebih dahulu dilakukan pemutakhiran. Pemutakhiran dilakukan oleh enumerator Riskesdas 2013 sebelum mulai melakukan wawancara.

Populasi dalam Riskesdas 2013 adalah seluruh rumah tangga biasa yang mewakili 33 provinsi. Sampel rumah tangga dalam Riskesdas 2013 dipilih berdasarkan listing Sensus Penduduk (SP) 2010. Proses pemilihan rumah tangga ditentukan oleh BPS yang memberikan daftar bangunan sensus terpilih yang berasal dari Blok Sensus terpilih.

\section{Populasi dan sampel analisis}

Populasi dalam penelitian ini adalah semua anggota rumah tangga dalam Riskesdas 2013 yang berumur 25-65 tahun. Sedangkan sampel adalah semua anggota rumah tangga Riskesdas 2013 yang berumur 25-65 tahun dengan kriteria tidak cacat fisik dan mental, sampel wanita tidak dalam keadaan hamil, dan mempunyai Indeks Massa Tubuh (IMT) minimal $18,5 \mathrm{~kg} / \mathrm{m}^{2}$ (batas IMT normal menurut WHO, 2000). ${ }^{10}$ Jumlah sampel pada awal analisis sebanyak 521.624. Setelah dilakukan koreksi terhadap nilai outliers dari variable tinggi badan, berat badan, dan beberapa variabel, serta kelengkapan data, maka jumlah sampel yang dianalisis sebanyak 458.591 .

\section{Data yang dianalisis}

Data yang dianalisis dalam Riskesdas 2013 diambil dari kuesioner rumah tangga (RKD13.RT) yang meliputi pengenalan tempat (klasifikasi desa/kelurahan), keterangan anggota rumah tangga (jenis kelamin, status kawin, umur, pendidikan, dan pekerjaan), status ekonomi. Status ekonomi pada Riskesdas 2013 menggunakan pendekatan perhitungan indeks kepemilikan. Sedangkan dari kuesiner individu (RKD13.IND) adalah kebiasaan merokok, aktifitas fisik, kebiasaan makan (makanan berlemak, roti, biskuit, mi instan, buah-buahan, dan sayuran), pengukuran (berat badan, tinggi badan).

\section{Pengukuran berat badan dan tinggi badan}

Pengukuran berat badan subyek umur 2565 tahun menggunakan timbangan berat badan digital merek "Fesco" dengan ketelitian 0,1 kg, yang dikalibrasi setiap hari. Selanjutnya untuk pengukuran tinggi badan diukur dengan alat ukur tinggi badan "Multifungsi" dengan kapasitas ukur dua meter dan ketelitian 0,1 cm.

\section{Pertimbangan etik analisis}

Pelaksanaan Riskesdas tahun 2013, telah memperoleh persetujuan etik dari Komisi Etik Penelitian Kesehatan (KEPK), Badan Penelitian dan Pengembangan Kesehatan Kementerian Kesehatan RI dengan nomor: LB.02.01/5.2/KE.006/2013.

\section{Analisis data \\ Pengolahan data diawali dengan menghitung IMT dari berat badan dan tinggi}


badan kemudian mengkategorisasi keadaan IMT menurut WHO (2000), yaitu: IMT= 18,524,9 (normal), IMT= 25,0-29,0 (overweight/gemuk) dan kelompok IMT $>30,0$ (obese)..$^{10} \mathrm{Di}$ samping itu juga dilakukan weighting tiap record sesuai dengan nilai inflate yang telah tersedia dalam file. Weight dihitung berdasarkan nilai inflate tiap record dibagi dengan nilai rata-rata inflate.

Selanjutnya analisis data dilakukan secara bertahap, yaitu analisis univariate, bivariate, dan multivariate. Analisis univariate ditujukan untuk mengetahui sebaran nilai masing-masing variabel. Sedangkan analisis bivariate bertujuan untuk mengetahui hubungan dependent variable, yaitu variable status gizi kegemukan dan status gizi obes dengan independent variable menggunakan uji Chi-square dan regresi logistik. Selanjutnya analisis multivariat dilakukan untuk mengetahui hubungan variabel independent secara bersama-sama dengan status gzi kegemukan maupun obese dengan menggunakan analisis regresi logistik multivariat model faktor risiko. Analisis multivariat dilakukan dengan menggunakan analisis regresi logistik. Variabel-variabel dengan nilai signifikan $p<0,25$ dipilih, kemudian dimasukkan dalam kandidat model multivariat. Semua analisis menggunakan perangkat lunak statistik.

\section{HASIL}

Jumlah sampel penelitian yang dianalisis sebanyak 458591 orang, terdiri dari laki-laki $217.940 \quad(47,5 \%)$ dan perempuan 240.651 $(52,5 \%)$. Hasil analisis univariat menunjukkan rata-rata umur responden $42,5 \pm 10,4$ tahun. Rata-rata Indeks Massa Tubuh (IMT) adalah $24,02 \pm 3,70 \mathrm{~kg} / \mathrm{m}^{2}$. Rata-rata IMT perempuan $(24,67 \pm 3,99)$ lebih tinggi daripada IMT laki-laki $(23,29 \pm 3,21)$. Prevalensi overweight pada usia 25-65 tahun ditemukan sebesar 26,1 persen (95\% Cl=26,03\%-26,28\%), sedangkan prevalensi obese pada usia 25-65 tahun sebesar 7,2 persen $(95 \% \mathrm{Cl}=7,12 \%-7,27 \%)$. Gambaran prevalensi overweight dan obese menurut karakteristik sampel dapat dilihat pada Tabel 1.

Tabel 1 menunjukkan bahwa kelompok umur responden berhubungan dengan risiko terjadinya overweight maupun obese. Responden pada kelompok umur 45-54 tahun memiliki risiko untuk terjadi overweight dan obese masing-masing sebesar 1,5 kali dan 1,6 kali dibandingkan responden pada kelompok umur 25-34 tahun. Perempuan memiliki risiko untuk terjadi overweight dan obese sebesar masing-masing 1,76 kali dan 3,43 kali dibandingkan dengan laki-laki. Responden di perkotaan memiliki risiko overweight dan obese masing-masing sebesar 1,57 kali dan 1,96 kali dibandingkan responden di perdesaan. Menurut tingkat pendidikan menunjukkan adanya kecenderungan peningkatan risiko overweight dan obese seiring dengan meningkatnya tingkat pendidikan responden. Responden yang sudah menikah memiliki risiko terjadi overweight dan obese masing-masing sebesar 2,13 kali dan 2,37 kali dibandingkan dengan responden yang belum menikah. Berdasarkan status ekonomi menunjukkan bahwa semakin tinggi kelompok kuintil status ekonomi semakin tinggi risiko untuk terjadi overweight maupun obese. Responden yang tidak pernah merokok berisiko untuk overweight dan obese masing-masing sebesar 1,89 kali dan 3,39 kali dibandingkan responden yang merokok. Sedangkan responden dengan aktivitas fisik kurang memiliki risiko untuk terjadi overweight dan obese masing-masing sebesar 1,7 kali dan 2,55 kali dibandingkan dengan responden dengan aktivitas fisik cukup. Dari hasil analisis bivariat (Tabel 1) menunjukkan bahwa karakteristik responden, yaitu: umur, jenis kelamin, wilayah, pendidikan, status menikah, pekerjaan, status ekonomi, kebiasaan merokok, dan aktivitas fisik masuk ke dalam tahap analisis mutivariat $(p<0,25)$.

Dari Tabel 2 menunjukkan bahwa responden dengan kebiasaan makan makanan berlemak $>=1$ kali per hari berisiko untuk terjadi overweight dan obese masing-masing sebesar 1,33 kali dan 1,51 kali dibandingkan dengan responden yang jarang mengonsumsi makanan berlemak. Kebiasaan makan roti >= 1 kali per hari berisiko untuk terjadi overweight dan obese masing-masing sebesar 1,43 kali dan 1,64 kali dibandingkan dengan yang jarang mengonsumsi roti. Kebiasaan makan biskuit >= 1 kali per hari berisiko untuk terjadi overweight dan obese masing-masing sebesar 1,37 kali dan 1,46 kali dibandingkan dengan yang jarang mengonsumsi biskuit. Responden yang jarang mengonsumsi mi instant berisiko untuk terjadi overweight dan obese masing-masing sebesar 
1,16 kali dan 1,3 kali dibandingkan dengan responden yang mengonsumsi mi instant $>=1$ kali per hari. Kebiasaan makan buah setiap hari berisiko untuk terjadi overweight dan obese masing-masing sebesar 1,99 kali dan 2,49 kali dibandingkan dengan yang tidak pernah makan buah. Kebiasaan makan sayuran setiap hari berisiko untuk terjadi overweight sebesar 1,16 kali dibandingkan yang tidak pernah makan sayuran. Sedangkan kebiasaan makan sayuran 1-6 hari mempunyai efek protekstif untuk terjadinya obese dibandingkan yang tidak pernah makan sayuran. Dari hasil analisis bivariat menunjukkan bahwa faktor kebiasaan makan makanan berlemak, roti, biskuit, mi instant, buah, dan sayuran masuk ke dalam tahap analisis mutivariat $(\mathrm{p}<0,25)$.

Tabel 1

Persentase Overweight dan Obese menurut Karakteristik Sampel

\begin{tabular}{|c|c|c|c|c|c|c|c|c|}
\hline \multirow{2}{*}{ Karakteristik sampel } & \multicolumn{2}{|c|}{ Normal (IMT 18,5-25) } & \multicolumn{3}{|c|}{ Overweight $(25>\mid \mathrm{MT}<30)$} & \multicolumn{3}{|c|}{ Obese $(I M T>=30)$} \\
\hline & $\mathrm{N}$ & $\%$ & $\mathrm{n}$ & $\%$ & OR crude $(95 \% \mathrm{Cl})$ & $\mathrm{n}$ & $\%$ & OR crude $(95 \% \mathrm{Cl})$ \\
\hline \multicolumn{9}{|l|}{ Kelompok umur } \\
\hline 25-34 tahun & 88.908 & 29,09 & 26.939 & 22,45 & 1 & 7.082 & 21,45 & 1 \\
\hline 35-44 tahun & 92.485 & 30,27 & 41.572 & 34,65 & $1,48(1,45-1,51)$ & 11.761 & 35,60 & $1,59(1,54-1,64)$ \\
\hline 45-54 tahun & 74.083 & 24,24 & 33.719 & 28,11 & $1,50(1,47-1,53)$ & 9.488 & 28,72 & $1,60(1,55-1,66)$ \\
\hline $55+$ & 50.107 & 16,40 & 17.745 & 14,79 & $1,16(1,14-1,19)$ & 4.702 & 14,23 & $1,17(1,13-1,22)$ \\
\hline \multicolumn{9}{|l|}{ Jenis kelamin } \\
\hline Laki-laki & 162.677 & 53,23 & 47.033 & 39,20 & 1 & 8.230 & 24,91 & 1 \\
\hline Perempuan & 142.906 & 46,77 & 72.942 & 60,80 & $1,76(1,74-1,78)$ & 24.803 & 75,09 & $3,43(3,34-3,52)$ \\
\hline \multicolumn{9}{|l|}{ Wilayah } \\
\hline Perdesaan & 175.249 & 57,35 & 55.207 & 46,02 & 1 & 13.425 & 40,64 & 1 \\
\hline Perkotaan & 130.334 & 42,65 & 64.768 & 53,98 & $1,57(1,55-1,59)$ & 19.608 & 59,36 & $1,96(1,91-2,00)$ \\
\hline \multicolumn{9}{|l|}{ Pendidikan } \\
\hline SD ke bawah & 161.782 & 52,94 & 53.526 & 44,61 & 1 & 14.574 & 44,12 & 1 \\
\hline SMP & 51.841 & 16,96 & 20.755 & 17,30 & $1,21(1,18-1,23)$ & 5.812 & 17,59 & $1,24(1,20-1,28)$ \\
\hline SMA & 69.123 & 22,62 & 32.322 & 26,94 & $1,41(1,39-1,43)$ & 8.893 & 26,92 & $1,42(1,38-1,46)$ \\
\hline PT & 22.837 & 7,48 & 13.372 & 11,15 & $1,76(1,72-1,81)$ & 3.754 & 11,37 & $1,82(1,75-1,89)$ \\
\hline \multicolumn{9}{|l|}{ Status kawin } \\
\hline Belum menikah & 26.348 & 8,62 & 5.089 & 4,24 & 1 & 1.260 & 3,81 & 1 \\
\hline Sudah menikah & 279.235 & 91,38 & 114.886 & 95,76 & $2,13(2,06-2,19)$ & 31.773 & 96,19 & $2,37(2,24-2,52)$ \\
\hline \multicolumn{9}{|l|}{ Pekerjaan } \\
\hline Petani, nelayan, buruh & 127.089 & 41,59 & 30.211 & 25,18 & 1 & 5.598 & 16,95 & 1 \\
\hline $\begin{array}{l}\text { Pegawai swasta, } \\
\text { wiraswasta }\end{array}$ & 83.532 & 27,34 & 37.597 & 31,34 & $1,89(1,86-1,92)$ & 10.214 & 30,92 & $2,77(2,68-2,87)$ \\
\hline PNS, TNI, POLRI & 15.588 & 5,10 & 10.661 & 8,88 & $2,87(2,79-2,95)$ & 2.924 & 8,85 & $4,25(4,06-4,46)$ \\
\hline Tidak bekerja & 79.374 & 25,97 & 41.506 & 34,60 & $2,19(2,16-2,23)$ & 14.297 & 43,28 & $4,08(3,95-4,22)$ \\
\hline \multicolumn{9}{|l|}{ Status ekonomi } \\
\hline Kuintil 1 & 61.971 & 20,28 & 13.428 & 11,19 & 1 & 2.550 & 7,72 & 1 \\
\hline Kuintil 2 & 61.732 & 20,20 & 18.369 & 15,31 & $1,37(1,33-1,40)$ & 4.637 & 14,04 & $1,82(1,73-1,91)$ \\
\hline Kuintil 3 & 62.826 & 20,56 & 23.711 & 19,76 & $1,74(1,70-1,78)$ & 6.345 & 19,21 & $2,45(2,34-2,57)$ \\
\hline Kuintil 4 & 60.612 & 19,84 & 29.929 & 24,95 & $2,27(2,22-2,33)$ & 8.906 & 26,96 & $3,57(3,41-3,73)$ \\
\hline Kuintil 5 & 58.442 & 19,12 & 34.538 & 28,79 & $2,72(2,66-2,79)$ & 10.595 & 32,07 & $4,40(4,21-4,60)$ \\
\hline \multicolumn{9}{|l|}{ Kebiasaan merokok } \\
\hline Merokok & 119.111 & 38,98 & 30.402 & 25,34 & 1 & 5.337 & 16,16 & 1 \\
\hline Pernah merokok & 13.585 & 4,45 & 5.871 & 4,89 & $1,69(1,63-1,75)$ & 1.416 & 4,29 & $2,32(2,18-2,47)$ \\
\hline Tidak pernah merokok & 172.887 & 56,57 & 83.702 & 69,77 & $1,89(1,86-1,92)$ & 26.280 & 79,55 & $3,39(3,29-3,49)$ \\
\hline \multicolumn{9}{|l|}{ Aktivitas fisik } \\
\hline Cukup & 129.020 & 42,22 & 35.975 & 29,99 & 1 & 7.356 & 22,27 & 1 \\
\hline Kurang & 176.563 & 57,78 & 84.000 & 70,01 & $1,70(1,68-1,73)$ & 25.677 & 77,73 & $2,55(2,48-2,62)$ \\
\hline Jumlah & 305.583 & 100,00 & 119.975 & 100,00 & & 33.033 & 100,00 & \\
\hline
\end{tabular}


Tabel 2

Persentase Overweight dan Obese menurut Kebiasaan Makan Makanan Berlemak, Roti, Biskuit, Mie Instant, Buah, dan Sayuran

\begin{tabular}{|c|c|c|c|c|c|c|c|c|}
\hline \multirow[t]{2}{*}{ Karakteristik } & \multicolumn{2}{|c|}{$\begin{array}{c}\text { Normal } \\
\text { (IMT 18,5-25) }\end{array}$} & \multicolumn{3}{|c|}{$\begin{array}{c}\text { Overweight } \\
(\text { IMT >25-<30) }\end{array}$} & \multicolumn{3}{|c|}{$\begin{array}{c}\text { Obese } \\
(\text { IMT > }=30)\end{array}$} \\
\hline & $\mathrm{N}$ & $\%$ & $\mathrm{n}$ & $\%$ & OR crude $(95 \% \mathrm{Cl})$ & $\mathrm{n}$ & $\%$ & $\mathrm{OR}_{\text {crude }}(95 \% \mathrm{Cl})$ \\
\hline \multicolumn{9}{|c|}{ Kebiasaan makanan berlemak } \\
\hline Jarang & 48.020 & 15,72 & 15.588 & 12,99 & 1 & 3.996 & 12,10 & 1 \\
\hline 1-6 kali/minggu & 158.086 & 51,73 & 61.420 & 51,19 & $1,19(1,17-1,22)$ & 16.530 & 50,04 & $1,25(1,21-1,30)$ \\
\hline$>=1$ kali per hari & 99.477 & 32,55 & 42.967 & 35,82 & $1,33(1,30-1,35)$ & 12.507 & 37,86 & $1,51(1,45-1,56)$ \\
\hline \multicolumn{9}{|l|}{ Kebiasaan makan roti } \\
\hline Jarang & 89.728 & 29,36 & 29.871 & 24,90 & 1 & 7.851 & 23,77 & 1 \\
\hline 1-6 kali/minggu & 173.552 & 56,79 & 69.851 & 58,22 & $1,20(1,19-1,22)$ & 19.087 & 57,78 & $1,25(1,22-1,29)$ \\
\hline >= 1 kali per hari & 42,303 & 13,85 & 20.253 & 16,88 & $1,43(1,40-1,46)$ & 6.095 & 18,45 & $1,64(1,58-1,70)$ \\
\hline \multicolumn{9}{|l|}{ Kebiasaan makan biskuit } \\
\hline Jarang & 108.384 & 35,47 & 37.668 & 31,40 & 1 & 10.256 & 31.05 & 1 \\
\hline 1-6 kali/minggu & 162.360 & 53,13 & 65.676 & 54,74 & $1,16(1,14-1,18)$ & 17.952 & 54,34 & $1,16(1,13-1,19)$ \\
\hline$>=1$ kali per hari & 34.839 & 11,40 & 16.631 & 13,86 & $1,37(1,34-1,40)$ & 4.825 & 14,61 & $1,46(1,41-1,51)$ \\
\hline \multicolumn{9}{|c|}{ Kebiasaan makan mie instant } \\
\hline >= 1 kali per hari & 24.890 & 8,15 & 9.140 & 7,62 & 1 & 2.436 & 7,37 & 1 \\
\hline 1-6 kali/minggu & 205.376 & 67,21 & 78.716 & 65,61 & $1,04(1,01-1,07)$ & 20.987 & 63,54 & $1,04(0,99-1,09)$ \\
\hline Jarang & 75.317 & 24,64 & 32.119 & 26,77 & $1,16(1,13-1,19)$ & 9.610 & 29,09 & $1,30(1,24-1,36)$ \\
\hline \multicolumn{9}{|l|}{ Kebiasaan makan buah } \\
\hline Tidak pernah & 43.311 & 14,17 & 12.979 & 10,82 & 1 & 3.322 & 10,06 & 1 \\
\hline 1-6 hari & 231.955 & 75,91 & 88.874 & 74,08 & $1,27(1,25-1,30)$ & 23.900 & 72,35 & $1,34(1,29-1,39)$ \\
\hline Setiap hari & 30.317 & 9,92 & 18.122 & 15,10 & $1,99(1,94-2,04)$ & 5.811 & 17,59 & $2,49(2,38-2,61)$ \\
\hline \multicolumn{9}{|c|}{ Kebiasaan makan sayuran } \\
\hline Tidak pernah & 3.206 & 1,05 & 1.169 & 0,97 & 1 & 381 & 1,15 & 1 \\
\hline $1-6$ hari & 124.061 & 40,60 & 43.377 & 36,16 & $0,95(0,89-1,02)$ & 11.267 & 34,11 & $0,76(0,68-0,85)$ \\
\hline Setiap hari & 178.316 & 58,35 & 75,429 & 62,87 & $1,16(1,08-1,24)$ & 21.385 & 64,74 & $1,00(0,90-1,12)$ \\
\hline Jumlah & 305.583 & 100,00 & 119.975 & 100,00 & & 33.033 & 100,00 & \\
\hline
\end{tabular}

Hasil analisis regresi logistik menunjukkan bahwa faktor risiko yang berhubungan dengan overweight pada orang dewasa umur 25-65 tahun adalah umur, jenis kelamin, wilayah, status kawin, pekerjaan, status ekonomi, dan kebiasaan merokok $(p<0,05)($ Tabel 3). Menurut kelompok umur, tampak adanya kecenderungan peningkatan risiko overweight sampai dengan kelompok umur 45-54 tahun. Responden pada kelompok umur 35-44 tahun mempunyai risiko overweight sebesar 1,40 kali $(95 \% \mathrm{Cl}: 1,38-1,43)$ dibandingkan responden pada kelompok umur 25-34 tahun. Responden pada kelompok umur 45-54 tahun mempunyai risiko overweight sebesar 1,41 kali $(95 \% \mathrm{Cl}$ : 1,38-1,43) dibandingkan responden pada kelompok umur 25-34 tahun.

Menurut jenis kelamin, dapat dijelaskan bahwa responden perempuan mempunyai risiko overweight sebesar 1,39 kali $(95 \% \mathrm{Cl}: 1,36-1,42)$ dibandingkan responden laki-laki. Selanjutnya responden yang bertempat tinggal di perkotaan mempunyai risiko overweigt sebesar 1,14 kali (95\% Cl: 1,12-1,16) dibandingkan responden yang tinggal di perdesaan.

Menurut jenis pekerjaan, responden yang bekerja sebagai PNS/TNI/POLRI paling berpotensi di antara dua jenis pekerjaan lainnya untuk menjadi overweight $(\mathrm{OR}=1,89)$ dibandingkan dengan responden yang bekerja sebagai petani/nelayan/buruh. Sedangkan menurut status ekonomi tampak adanya kecenderungan peningkatan overweight seiring dengan kenaikan kelompok kuintil status ekonomi. Selanjutnya menurut kebiasaan merokok, didapatkan peningkatan potensi risiko overweight pada responden pernah merokok $(\mathrm{OR}=1,43)$ dan responden yang tidak pernah merokok $(O R=1,32)$ dibandingkan responden yang merokok. 
Tabel 3

Model Regresi Logistik Faktor Risiko Overweight pada Orang Dewasa 25-65 Tahun

\begin{tabular}{|c|c|c|c|}
\hline Faktor risiko & OR $\mathrm{R}_{\text {Ajjusted }}$ & Cl 95\% & $\mathrm{p}$ \\
\hline \multicolumn{4}{|l|}{ Kelompok umur } \\
\hline 25-34 tahun & 1 & & \\
\hline 35-44 tahun & 1,40 & $1,38-1,43$ & 0,000 \\
\hline 45-54 tahun & 1,41 & $1,38-1,43$ & 0,000 \\
\hline $55+$ & 1,13 & $1,10-1,15$ & 0,000 \\
\hline \multicolumn{4}{|l|}{ Jenis kelamin } \\
\hline Laki-laki & 1 & & \\
\hline Perempuan & 1,39 & $1,36-1,42$ & 0,000 \\
\hline \multicolumn{4}{|l|}{ Wilayah } \\
\hline Perdesaan & 1 & & \\
\hline Perkotaan & 1,14 & $1,12-1,16$ & 0,000 \\
\hline \multicolumn{4}{|l|}{ Status kawin } \\
\hline Belum menikah & 1 & & \\
\hline Sudah menikah & 1,83 & $1,77-1,89$ & 0,000 \\
\hline \multicolumn{4}{|l|}{ Pekerjaan } \\
\hline Petani, nelayan, buruh & 1 & & \\
\hline Pegawai swasta, wiraswasta & 1,48 & $1,45-1,51$ & 0,000 \\
\hline PNS, TNI, POLRI & 1,89 & $1,83-1,95$ & 0,000 \\
\hline Tidak bekerja & 1,45 & $1,42-1,48$ & 0,000 \\
\hline \multicolumn{4}{|l|}{ Status ekonomi } \\
\hline Kuintil 1 & 1 & & \\
\hline Kuintil 2 & 1,26 & $1,23-1,30$ & 0,000 \\
\hline Kuintil 3 & 1,49 & $1,45-1,53$ & 0,000 \\
\hline Kuintil 4 & 1,79 & $1,74-1,83$ & 0,000 \\
\hline Kuintil 5 & 1,96 & $1,91-2,01$ & 0,000 \\
\hline \multicolumn{4}{|l|}{ Kebiasaan merokok } \\
\hline Merokok & 1 & & \\
\hline Pernah merokok & 1,43 & $1,39-1,48$ & 0,000 \\
\hline Tidak pernah merokok & 1,32 & $1,29-1,35$ & 0,000 \\
\hline
\end{tabular}

Hasil analisis regresi logistik pada Tabel 4 menunjukkan bahwa faktor risiko yang berhubungan dengan obese pada orang dewasa umur 25-65 tahun adalah umur, jenis kelamin, wilayah, status kawin, pekerjaan, status ekonomi, kebiasaan merokok, kebiasaan makan roti, dan kebiasaan makan biskuit $(p<0,05)$. Menurut kelompok umur, tampak adanya kecenderungan peningkatan risiko obese sampai dengan kelompok umur 45-54 tahun.

Menurut jenis kelamin, dapat dijelaskan bahwa responden perempuan mempunyai risiko obese sebesar 2,70 kali (95\% Cl: 2,59-2,82) dibandingkan responden laki-laki. Selanjutnya responden yang bertempat tinggal di perkotaan mempunyai risiko obese sebesar 1,24 kali
(95\% Cl: 1,21-1,28) dibandingkan responden yang tinggal di perdesaan.

Menurut jenis pekerjaan, responden yang bekerja sebagai PNS/TNI/POLRI paling berpotensi di antara dua jenis pekerjaan lainnya untuk menjadi obese $(\mathrm{OR}=2,31)$ dibandingkan dengan responden yang bekerja sebagai petani/nelayan/buruh. Sedangkan menurut status ekonomi tampak adanya kecenderungan peningkatan obese seiring dengan kenaikan kelompok kuintil status ekonomi. Selanjutnya menurut kebiasaan merokok, didapatkan peningkatan potensi risiko obese pada responden pernah merokok $(O R=1,78)$ dan responden yang tidak pernah merokok $(\mathrm{OR}=1,28)$ dibandingkan responden yang merokok. 
Selanjutnya dilihat dari kebiasaan makan responden didapatkan hasil bahwa responden dengan kebiasaan makan roti satu kali per hari atau lebih mempunyai risiko untuk obese sebesar 1,19 kali $(95 \% \mathrm{Cl}: \quad 1,13-1,26)$ dibandingkan responden yang jarang makan roti. Sebaliknya pada responden dengan kebiasaan makan biskuit satu kali per hari atau lebih mempunyai dampak protektif untuk terjadinya obese $(\mathrm{OR}=0,84)$ dibandingkan responden yang jarang makan biskuit.

Tabel 4

Model Regresi Logistik Faktor Risiko Obese pada Orang Dewasa 25-65 Tahun

\begin{tabular}{|c|c|c|c|}
\hline Faktor risiko & $\mathrm{OR}_{\text {Adjusted }}$ & $\mathrm{Cl} 95 \%$ & $\mathrm{p}$ \\
\hline \multicolumn{4}{|l|}{ Kelompok umur } \\
\hline 25-34 tahun & 1 & & \\
\hline 35-44 tahun & 1,57 & $1,52-1,62$ & 0,000 \\
\hline 45-54 tahun & 1,61 & $1,55-1,67$ & 0,000 \\
\hline $55+$ tahun & 1,21 & $1,16-1,26$ & 0,000 \\
\hline \multicolumn{4}{|l|}{ Jenis kelamin } \\
\hline Laki-laki & 1 & & \\
\hline Perempuan & 2,70 & $2,59-2,82$ & 0,000 \\
\hline \multicolumn{4}{|l|}{ Wilayah } \\
\hline Perdesaan & 1 & & \\
\hline Perkotaan & 1,24 & $1,21-1,28$ & 0,000 \\
\hline \multicolumn{4}{|l|}{ Status kawin } \\
\hline Belum menikah & 1 & & \\
\hline Sudah menikah & 1,87 & $1,76-1,98$ & 0,000 \\
\hline \multicolumn{4}{|l|}{ Pekerjaan } \\
\hline Petani, nelayan, buruh & 1 & & \\
\hline Pegawai swasta, wiraswasta & 1,91 & $1,84-1,98$ & 0,000 \\
\hline PNS, TNI, POLRI & 2,31 & $2,19-2,43$ & 0,000 \\
\hline Tidak bekerja & 1,91 & $1,84-1,98$ & 0,000 \\
\hline \multicolumn{4}{|l|}{ Status ekonomi } \\
\hline Kuintil 1 & 1 & & \\
\hline Kuintil 2 & 1,60 & $1,52-1,69$ & 0,000 \\
\hline Kuintil 3 & 1,93 & $1,83-2,03$ & 0,000 \\
\hline Kuintil 4 & 2,49 & $2,37-2,62$ & 0,000 \\
\hline Kuintil 5 & 2,76 & $2,63-2,90$ & 0,000 \\
\hline \multicolumn{4}{|l|}{ Kebiasaan merokok } \\
\hline Merokok & 1 & & \\
\hline Pernah merokok & 1,78 & $1,67-1,90$ & 0,000 \\
\hline Tidak pernah merokok & 1,28 & $1,23-1,34$ & 0,000 \\
\hline \multicolumn{4}{|l|}{ Kebiasaan makan roti } \\
\hline Jarang & 1 & & \\
\hline 1-6 kali/minggu & 1,04 & $1,00-1,08$ & 0,036 \\
\hline$>=1$ kali per hari & 1,19 & $1,13-1,26$ & 0,000 \\
\hline \multicolumn{4}{|l|}{ Kebiasaan makan biskuit } \\
\hline Jarang & 1 & & \\
\hline 1-6 kali/minggu & 0,90 & $0,87-0,93$ & 0,000 \\
\hline$>=1$ kali per hari & 0,84 & $0,80-0,89$ & 0,000 \\
\hline
\end{tabular}




\section{BAHASAN}

Hasil penelitian menunjukkan prevalensi overweight dan obese pada usia 25-65 tahun di Indonesia masing-masing sebesar 26,16 persen dan 7,20 persen. Bila dibandingkan dengan penelitian di negara lain masih relatif lebih rendah. Penelitian di Tanzania 2007-2008 mendapatkan prevalensi overweight dan obese pada umur 18-65 tahun masing-masing sebesar 19,2 persen dan 24,1 persen. ${ }^{17}$ Sedangkan penelitian Mir Islam SK dan Rasooly MH (2013) pada responden umur 40 tahun ke atas di Kota Kabul, Afganistan menunjukkan prevalensi overweight sebesar 38,1 persen dan obese sebesar 31,2 persen. ${ }^{18}$ Penelitian Ghorbani $R$ dkk. (2015) pada wanita umur 40-60 tahun di Iran mendapatkan prevalensi overweight sebesar 45,4 persen dan obese sebesar 35,4 persen. ${ }^{19}$ Penelitian Oanh dkk. (2009) di Vietnam yang mendapatkan hasil prevalensi overweight dan obese pada umur 25-64 tahun masing-masing sebesar 13,9 persen dan 1,8 persen. ${ }^{20}$ Penelitian Sidik SM dan Rampal $\mathrm{L}$ (2009) pada 1032 wanita umur 20-59 tahun di Malaysia mendapatkan prevalensi obese sebesar 16,7 persen. ${ }^{21}$

Hasil penelitian ini menunjukkan adanya hubungan antara umur responden dengan prevalensi overweight dan obese. Prevalensi overweight maupun obese cenderung meningkat sampai dengan kelompok umur 4554 tahun dan cenderung menurun pada umur 55 tahun ke atas. Hasil penelitian ini sejalan dengan penelitian lainnya. ${ }^{17-21} \mathrm{Hal}$ ini terkait dengan penurunan aktivitas fisik dan penurunan metabolisme seiring dengan meningkatnya umur. 17,22

Pada penelitian ini menunjukkan bahwa prevalensi overweight dan obese lebih tinggi pada perempuan dibandingkan dengan laki-laki. Tingginya prevalensi overweight dan obese pada perempuan dibandingkan dengan laki-laki secara signifikan juga didapatkan pada penelitian di Tanzania ${ }^{17}$, Afganistan ${ }^{18}$, dan Afrika Barat ${ }^{23}$. Penelitian sebelumnya yang dilakukan oleh Rahmawati $(2008)^{24}$ dan Sugianti, dkk. (2009) ${ }^{25}$ juga menunjukkan perbedaan yang signifikan prevalensi overweigt dan obese menurut jenis kelamin. Hal tersebut dapat dijelaskan karena adanya perbedaan dalam variasi faktor risiko (misalnya: faktor konsumsi makanan, kurangnya aktivitas fisik, faktor genetik) antara laki-laki dan perempuan. ${ }^{22}$ Penelitian Gbary, dkk. (2014) mendapatkan adanya faktor budaya, faktor perilaku, dan faktor psikososial terkait dengan obese pada perempuan di Afrika Barat. ${ }^{23}$ Simkin-Silverman LR dan Wing RR (2000) menyatakan bahwa pada wanita menopause berhubungan dengan peningkatan berat badan, central adiposity yang meningkat, dan menurunnya aktivitas fisik. Peningkatan berat badan yang disebabkan oleh perubahan hormonal terjadi pada saat peralihan masa menopause. ${ }^{26}$ Namun pada hasil penelitian Sternfeld B, dkk. (2004) tidak menunjukkan adanya hubungan antara status menopause dengan peningkatan berat badan. ${ }^{27}$

Prevalensi overweight dan obese juga lebih banyak ditemukan di perkotaan dibandingkan dengan di perdesaan. Penelitian ini sejalan dengan penelitian di Vietnam ${ }^{20}$ dan Afrika Barat $^{23}$. Perubahan gaya hidup pada masyarakat di perkotaan, seperti: konsumsi makanan cepat saji yang menyebabkan ketidakseimbangan makanan, aktivitas fisik yang kurang yang disebabkan oleh pekerjaan sedentary dan penggunaan alat-alat elektronik dan kendaraan bermotor.28,29 Selain itu kurangnya sarana dan fasilitas olahraga di perkotaan juga menyebabkan masyarakat perkotaan lebih nyaman tinggal di rumah. ${ }^{23}$

Menurut status perkawinan, hasil penelitian ini mendapatkan bahwa prevalensi overweight dan obese berpotensi terjadi pada responden yang sudah menikah dibandingkan yang belum menikah. Hasil penelitian sejenis juga didapatkan oleh Sugianti, dkk. (2009) ${ }^{25}$. Sebaliknya hasil penelitian Shayo GA dkk.(2011) ${ }^{17}$ dan Ghorbani R, dkk. (2015) $)^{19}$ tidak menunjukkan adanya keterkaitan antara status kawin dengan prevalensi overweight dan obese. Menurut Wamala SP, dkk. (1997) bahwa riwayat reproduksi pada wanita (paritas, umur awal menarche) terkait dengan obese. ${ }^{30}$

Dilihat dari faktor pekerjaan hasil penelitian ini menunjukkan adanya hubungan antara jenis pekerjaan dengan prevalensi overweight dan obese. Hasil penelitian ini sejalan dengan penelitian, Cihangir E, dkk. (2004)22, Gbary, dkk. (2014) ${ }^{23}$, dan Sugianti, dkk. (2009) ${ }^{25}$. Tingginya prevalensi overweight dan obese pada responden yang bekerja sebagai PNS, TNI, POLRI, pegawai swasta, wiraswasta 
dimungkinkan karena faktor kemudahan dalam mendapatkan konsumsi makanan terkait dengan pendapatan yang diperoleh dibandingkan dengan jenis pekerjaan petani, nelayan, dan buruh. Selain itu kemudahan yang didapatkan di tempat bekerja, seperti peralatan elektronik, transportasi dimungkinkan juga menyebabkan aktivitas fisik yang berkurang (banyak duduk) yang selanjutnya mengakibatkan peningkatan berat badan. Menurut Cihangir E, dkk. (2004) bahwa pada ibu rumah tangga yang tidak bekerja cenderung lebih mudah untuk mendapatkan akses makanan selama di rumah yang berkontribusi untuk terjadinya obese. ${ }^{22}$

Menurut status ekonomi juga menunjukkan adanya peningkatan prevalensi overweight dan obese seiring dengan meningkatnya kelompok kuintil status ekonomi. Pada penelitian lainnya juga menunjukkan bahwa peningkatan status ekonomi menyebabkan peningkatan prevalensi overweight dan obese. 17,20,25 Peningkatan status ekonomi menyebabkan kenaikan dalam konsumsi gula, garam, makanan fast food, protein hewani, minyak jenuh, dan kurangnya aktivitas fisik yang dapat mengakibatkan peningkatan overweight maupun obese. ${ }^{17}$

Penelitian ini juga menunjukkan adanya hubungan antara kebiasaan merokok dengan prevalensi overweight dan obese. Hasil penelitian Cihangir E, dkk. (2004) $)^{22}$, Sugianti, dkk. (2009) ${ }^{25}$, dan Xuhong, dkk. (2008) ${ }^{31}$ juga menunjukkan adanya hubungan antara kebiasaan merokok dengan prevalensi overweight dan obese. Hasil penelitian ini menunjukkan bahwa responden yang pernah merokok maupun responden yang tidak merokok cenderung berisiko untuk overweight ataupun obese dibandingkan responden yang merokok. Berhenti merokok biasanya dikaitkan dengan peningkatan berat badan dan perubahan dalam metabolisme sel adipose yang berakibat terhadap peningkatan aktivitas enzim lipoprotein lipase dalam jaringan adipose. Peningkatan aktivitas enzim lipoprotein lipase tersebut berperan dalam peningkatan berat badan yang berkaitan dengan berhenti merokok. 32,33

Selanjutnya pada penelitian ini menunjukkan adanya hubungan antara kebiasaan makan roti dan kebiasaan makan biskuit dengan prevalensi obese. Hasil tersebut merupakan temuan baru dibandingkan dengan hasil penelitian Kodyat, dkk. (1996) dan Riset Kesehatan Dasar 2007.6,7 Responden yang mengonsumsi roti 1-6 kali/minggu maupun >= 1 kali per hari lebih berisiko untuk obese dibandingkan yang jarang mengonsumsi roti. Sedangkan konsumsi biskuit dalam penelitian ini menunjukkan efek protektif terhadap terjadinya obese. Penelitian Hardinsyah dan Amalia (2007) menunjukkan bahwa konsumsi terigu dan olahannya di perkotaan lebih tinggi dibandingkan dengan di perdesaan. ${ }^{34}$ Hasil Survei Konsumsi Makanan Individu Indonesia (SKMI) tahun 2014 menunjukkan bahwa konsumsi serealia penduduk Indonesia didominasi oleh beras dan olahannya kemudian diikuti oleh terigu dan olahannya. Konsumsi rata-rata terigu dan olahan terigu (roti manis, roti tawar, biskuit, dll) di Indonesia pada dewasa umur 19 tahun ke atas masing masing sebesar 17,5 gram per orang per hari dan 15,6 gram per orang per hari. ${ }^{35}$ Penganekaragaman makanan pokok telah dijelaskan dalam Pedoman Gizi Seimbang, yaitu dengan mengonsumsi lebih dari satu jenis makanan pokok dalam sehari atau sekali makan, seperti dengan mencampur karbohidrat lokal dengan terigu. ${ }^{36}$ Konsumsi terigu dan olahannya (termasuk roti) yang berlebih di samping makanan pokok yang sudah dikonsumsi dalam setiap kali makan akan menimbulkan kelebihan karbohidrat, lemak, dan protein dalam tubuh. Sebagaimana diketahui kandungan zat gizi per porsi makanan pokok mengandung 175 Kalori, 4 gram protein, dan 40 gram karbohidrat. ${ }^{36}$ Keterkaitan antara konsumsi roti dan biskuit dapat dijelaskan dari hasil review 38 penelitian epidemiologi yang dilakukan oleh Bautista-Castaño I dan SerraMajem L (2012) menunjukkan bahwa konsumsi roti gandum (whole-grain bread) lebih menguntungkan daripada roti halus (refined bread), terutama dalam kaitannya dengan distribusi lemak perut. Pola diet yang mencakup roti gandum tidak mempengaruhi berat badan. Pola diet yang mencakup halus roti pada sebagian besar studi cross-sectional menunjukkan efek menguntungkan, namun pada sebagian besar studi kohor menunjukkan kemungkinan hubungan dengan kelebihan lemak perut. ${ }^{37}$

Hasil analisis multivariat dalam penelitian ini belum menunjukkan hubungan antara aktivitas fisik dengan prevalensi overweight dan obese. Sedangkan pada penelitian sebelumnya yang membuktikan adanya hubungan antara aktivitas fisik dengan overweight dan obese. .7,38 $^{17}$ 
Menurut Haskell, dkk. (2007) untuk menjaga kesehatan usia 18-65 tahun dibutuhkan aktivitas fisik sedang selama minimal 30 menit (lima hari dalam satu minggu) atau aktivitas fisik berat selama minimal 20 menit (tiga hari dalam satu minggu). ${ }^{39}$

\section{SIMPULAN DAN SARAN}

\section{Simpulan}

Faktor risiko terkait dengan overweight dan obese adalah umur, jenis kelamin, wilayah, status kawin, pekerjaan, status ekonomi, kebiasaan merokok. Selanjutnya diperoleh hasil juga bahwa kebiasaan makan roti dan kebiasaan makan biskuit berhubungan dengan kejadian obese.

\section{Saran}

Dengan melihat kecenderungan peningkatan overweight dan obese pada umur 25-65 tahun diperlukan upaya pencegahan seperti dengan aktivitas fisik yang cukup setiap hari secara berkesinambungan. Di samping itu diperlukan upaya promosi pemilihan makanan pengganti sumber karbohidrat dalam pemenuhan gizi seimbang baik dalam jumlah maupun jenis, serta kualitasnya.

\section{UCAPAN TERIMA KASIH}

Penulis mengucapkan terima kasih kepada Kepala Badan Penelitian dan Pengembangan Kesehatan Kementerian Kesehatan Rl yang telah memberikan ijin dalam pengolahan data Riskesdas 2013.

\section{RUJUKAN}

1. Nguyen $M$, Fleming $T$, Robinson $M$, Thomson B, Graetz N, Margono C, Mullany EC, Biryukov S, Abbafati C, Abera SF, et al. Global, regional, and national prevalence of overweight and obesity in children and adults during 1980-2013: a systematic analysis for the Global Burden of Disease Study 2013. Lancet. 2014; 384 (9945): 766-781.

2. Caballero B. The global epidemic of obesity: an overview. Epidemiol Rev. 2007; 29: $1-5$.
3. Low S, Mien CC, Deurenberg-Yap M. Review on Epidemic of Obesity. Annals Academy of Medicine. 2009; 38(1):57-65

4. Finucane MM, Stevens GA, Cowan MJ, Danaei G, Lin JK, Paciorek CJ, Singh GM, Gutierrez HR, Lu Y, Bahalim AN et al. National, regional, and global trends in body mass index since 1980: systematic analysis of health examination surveys and epidemiological studies with 960 countryyears and 9.1 million participants. Lancet. 2011; 337(9765):555-567. DOI: http://dx.doi.org/10.1016/S01406736(10)62037-5

5. Kastorini $\mathrm{CM}$, Milionis $\mathrm{HJ}$, loannidi $\mathrm{A}$, Kalantzi K, Nikolaou V, Vemmos KN, Goudevenos JA, Panagiotakos DB. Adherence to the Mediterranean diet in relation to acute coronary syndrome or stroke nonfatal events: A comparative analysis of a case/case-control study. Am Heart J.2011; 162(4):717-24. DOI: http://dx.doi.org/10.1016/j.ahj.2011.07. 012.

6. Kodyat BA, Minarto, Raoef R, Pardede LV, Sianturi G, Iryanis. Survei Indek Massa Tubuh (IMT) di 12 Kotamadya, Indonesia. Gizi Indon. 1996; 21: 52-61.

7. Sudikno, Milla Herdayati, Besral. Hubungan aktivitas fisik dengan kejadian obesitas pada orang dewasa di Indonesia (Analisis data Riskesdas 2007). Gizi Indonesia. 2010; 33 (1): 37-49.

8. Kementerian Kesehatan. Pokok-pokok Hasil Riskesdas 2013. Jakarta (ID): Badan Litbang Kesehatan; 2014.

9. Lee YS, So JBY, Deurenberg-Yap M. Confronting the Obesity Epidemic: Call to Arms. Annals Academy of Medicine. 2009; 38(1)

10. World Health Organization. Obesity: Preventing and Managing the Global Epidemic. Report of a WHO Consultation. Geneva: WHO; 2000.

11. Truesdale KP, Stevens J, Lewis CE, Schreiner PJ, Loria CM, Cai J. Changes in risk factors for cardiovascular disease by baseline weight status in young adults who maintain or gain weight over 15 years: the CARDIA study. Int J Obesity. 2006; 30:1397-1407

12. Lestari $H$, Siswanto. Pemodelan Risiko Kejadian Diabetes Mellitus (Analisis Data 
Surkesnas 2004). Buletin Penelitian Kesehatan. 2007; 35(1):25-35.

13. Sihombing M, Tjandrarini DH. Faktor Risiko Sindrom Metabolik pada Orang Dewasa di Kota Bogor. Penelitian Gizi dan Makanan. 2015;38 (1): 21-30.

14. Mukherjee B, Hossain CM, Mondal L, Paul P, Ghosh MK. Review: Obesity and Insulin Resistance: An Abridged Molecular Correlation. Lipid Insights. 2013; 6: 1-11. doi: 10.4137/LPI.S10805.

15. Tee ES. Priority nutritional concerns in Asia. Food and Nutrition Bulletin. 2002; 23(4): 345-348.

16. Popkin BM, Adair LS, Nguyen SW. Now And Then: The Global Nutrition Transition: The Pandemic of Obesity in Developing Countries. Nutr Rev. 2012; 70(1): 3-21. doi:10.1111/j.1753-4887.2011.00456.x.

17. Shayo GA, Mugusi FM. Prevalence of obesity and associated risk factors among adults in Kinondoni municipal district, Dar es Salaam Tanzania. BMC Public Health. 2011; $11: 365$. http://www.biomedcentral.com/14712458/11/365.

18. Mir Islam SK, Rasooly MH. Prevalence and Risk Factors Associated with Obesity among Adult Kabul Citizens (Afghanistan), 2012. Iranian Journal of Diabetes and Obesity. 2013; 4 (4): 152-161.

19. Ghorbani R, Nassaji M, Jandaghi J, Rostami B, Ghorbani N. Overweight and Obesity and Associated Risk Factors among the Iranian Middle-Aged Women. International Journal of Collaborative Research on Internal Medicine \& Public Health. 2015; 7 (6):120-131

20. Oanh TT, Nguyen DN, Philayrath $P$, Dibley MJ, Bauman AE. Prevalence and risk factors with overweight and obesity among Vietnamese adults: Caucasian and Asian cut-offs. Asia Pac J Clin Nutr. 2009; 18 (2): 226-233.

21. Sidik SM, Rampal L. The prevalence and factors associated with obesity among adult women in Selangor, Malaysia. Asia Pacific Family Medicine. 2009; 8:2. doi:10.1186/1447-056X-8-2

22. Cihangir $E$, Cengiz $A$, Hacihasanoglu $A$, Orhan D, Topbas M, Ukinc K, Ersoz HO, Telatar M. Prevalence of Obesity and Associated risk factors in a Turkish population (Trabzon City, Turkey). Obesity research. 2004; 12:1117-1127.

23. Gbary AR, Kpozehouen A, Houehanou YC, Djrolo F, Amoussou MPG, Tchabi Y, Salamon R, Houinato DS. Prevalence and risk factors of overweight and obesity: findings from a cross-sectional communitybased survey in Benin. Global Epidemic Obesity. 2014;1-8. doi: 10.7243/2052-59662-3.

24. Rahmawati, Sudikno. Faktor-Faktor yang Berpengaruh terhadap Status Gizi Obesitas Orang Dewasa di Kota Depok, Tahun 2007. Gizi Indon. 2008; 31(1):35-48.

25. Sugianti $E$, Hardinsyah, Afriansyah $N$. Faktor Risiko Obesitas Sentral pada Orang Dewasa di DKI Jakarta: Analisis Lanjut Data Riskesdas 2007. Gizi Indon. 2009; 32(2):105-116.

26. Simkin-Silverman LR, Wing RR. Weight gain during menopause. Is it inevitable or can it be prevented?. Postgrad Med. 2000;108(3):47-50.

27. Sternfeld B, Wang $H$, Quesenberry CP Jr et al. Physical activity and changes in weight and waist circumference in midlife women: findings from the Study of Women's Health Across the Nation. Am J Epidemiol. 2004;160(9):912-922.

28. Mokhtar N, Elati J, Chabir R, Bour A, Elkari $\mathrm{K}$, Schlossman NP, Caballero $B$ and Aguenaou H. Diet culture and obesity in northern Africa. J Nutr. 2001; 131:887S8925

29. Musaiger AO and Al-Mannai MA. Weight, height, body mass index and prevalence of obesity among the adult population in Bahrain. Ann HumBiol. 2001; 28:346-50

30. Wamala SP, Wolk A, Orth-Gomer K. Determinants of obesity in relation to socioeconomic status among middleaged Swedish women. Prev Med. 1997;26:73444.

31. Xuhong $H$, Weiping $J$, Yuqian $B$, Huijuan $L$, Shan J, Yuhua Z, Huilin G, Kunsan X. Risk factors for overweight and obesity, and changes in body mass index of Chinese adults in Shanghai. BMC Public Health. 2008; 8:389. doi:10.1186/1471-2458-8-389.

32. Owen-Smith V, Hannaford PC. Stopping smoking and body weight in women living 
in the United Kingdom. $\mathrm{Br} \mathrm{J}$ Gen Prac. 1999:49:989-90.

33. Ferrara CM, Kumar M, Nicklas B, McCrone S, Goldberg AP. Weight gain and adipose tissue metabolism after smoking cessation in women. Int J Obes Relat Metab Disord. 2001;25: 1322-6.

34. Hardinsyah dan Amalia L. Perkembangan Konsumsi Terigu dan Pangan Olahannya di Indonesia 1993-2005. Jurnal Gizi dan Pangan, 2007; 2(1):8-15

35. Kementerian Kesehatan RI. Buku Survei Konsumsi Makanan Individu dalam Studi Diet Total 2014. Jakarta (ID): Lembaga Penerbitan Badan Litbangkes; 2014.

36. Kementerian Kesehatan RI. Pedoman Gizi Seimbang (Pedoman Teknis Bagi Petugas Dalam Memberikan Penyuluhan Gizi Seimbang). Direktorat Jenderal Bina Gizi dan Kesehatan Ibu dan Anak. Jakarta (ID): Kementerian Kesehatan RI. 2014.
37. Bautista-Castaño I, Serra-Majem L. Relationship between bread consumption, body weight, and abdominal fat distribution: evidence from epidemiological studies. Nutrition Reviews. 2012; 70(4):218-233. doi: 10.1111/j.1753-4887.2012.00454.x.

38. Alsaif MA, Iman A. Hakim IA, Harris RB, Alduwaihy M, Al-Rubeaan K, Al-Nuaim AR, Al-Attas OS. Prevalence and risk factors of obesity and overweight in adult Saudi population. Nutrition Research. 2002; 22:1243-1252.

39. Haskell WL, I-Min L, Pate RR, Powell KE, Blair SN, Franklin BA, Macera CA, Heath GW, Thompson PD, Adrian Bauman A . Physical activity and public health updated recommendation for adults from the American College of Sports Medicine and the American Heart Association. Circulation. 2007; 116:1081-1093. DOI: 10.1161/CIRCULATIONAHA.107.185649. 
